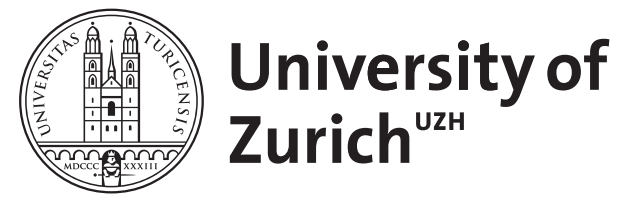

\title{
Genetic association study on colony-stimulating factor 1 in Alzheimer's disease
}

\author{
Wollmer, M A ; Nitsch, R M ; Hock, C ; Papassotiropoulos, A
}

\begin{abstract}
These data do not support the hypothesis that genetic variability of CSF1 influences the risk for $\mathrm{AD}$.
\end{abstract}

DOI: https://doi.org/10.1159/000097302

Posted at the Zurich Open Repository and Archive, University of Zurich ZORA URL: https://doi.org/10.5167/uzh-49398

Journal Article

Published Version

Originally published at:

Wollmer, M A; Nitsch, R M; Hock, C; Papassotiropoulos, A (2006). Genetic association study on colonystimulating factor 1 in Alzheimer's disease. Neurodegenerative Diseases, 3(6):334-337.

DOI: https://doi.org/10.1159/000097302 


\title{
Genetic Association Study on Colony-Stimulating Factor 1 in Alzheimer's Disease
}

\author{
M. Axel Wollmer Roger M. Nitsch Christoph Hock Andreas Papassotiropoulos
}

Division of Psychiatry Research, University of Zurich, Zurich, Switzerland

\section{Key Words}

Microglia • $\beta$-Amyloid · Polymorphism • Macrophage

\begin{abstract}
Background: Colony-stimulating factor 1 (CSF1) regulates the proliferation and differentiation of myelomonocytic cells. Microglial cells of CSF1-deficient mice are reduced in number and are functionally impaired. CSF1-deficient mice exhibit subtle neurodevelopmental defects, enhanced neuronal vulnerability. Moreover, it has been reported that these mice may have amyloid-plaque-like depositions in the brain at an early age. The human CSF1 gene maps to chromosome 1p21-p13, a region previously linked to Alzheimer's disease (AD). Thus, CSF1 is a functional and positional candidate gene for AD. Objective: We assessed if genetic variability of CSF1 may influence the risk for AD. Methods: We conducted a population-based case-control association study with 3 single nucleotide polymorphisms (SNPs) across the CSF1 locus in a sample of $n=185$ ( $r$ 3093054, rs756325) and $n=327$ (rs1058885) individuals. Results: None of the 3 investigated SNPs was associated with the risk for AD in our sample. Conclusion: These data do not support the hypothesis that genetic variability of CSF1 influences the risk for AD.
\end{abstract}

Copyright $\odot 2006$ S. Karger AG, Basel

\begin{tabular}{ll}
\hline KARGER & (c) 2006 S. Karger AG, Basel \\
Fax $+41660-2854 / 06 / 0036-0334 \$ 23.50 / 0$ \\
$\begin{array}{l}\text { E-Mail karger@karger.ch } \\
\text { www.karger.com }\end{array}$ & $\begin{array}{l}\text { Accessible online at: } \\
\text { www.karger.com/ndd }\end{array}$
\end{tabular}

Colony-stimulating factor 1 (CSF1) regulates the proliferation and differentiation of myelomonocytic cells and is involved in the initiation and maintenance of the macrophage immune response. Microglia are the resident macrophages of the CNS. They are supposed to contribute to the removal of $\beta$-amyloid (A $\beta)$ from the brain [1]. Especially brain macrophages of myelomonocytic origin seem to restrict cerebral amyloid deposition [2]. $\mathrm{A} \beta$ increases neuronal expression of CSF1 [3], and neuronal damage leads to up-regulation of both CSF1 and its receptor in microglial cells [4]. CSF1 enhances the capacity of microglial cells to phagocytose $A \beta$ [5]. Thus, upregulation of CSF1 in Alzheimer's disease (AD) and in APP-transgenic mice $[3,6]$ may represent the, admittedly insufficient, activation of an $A \beta$ clearance pathway. CSF1-deficient osteopetrotic (op/op) mice have reduced numbers and functional impairment of myelomonocytic cells including microglia [7-9]. Observations suggesting that these mice may deposit congophilic, $A \beta$ antibodyreactive material in the brain resembling amyloid plaques of $\mathrm{AD}$ patients and APP-transgenic mice have been reported $[10,11]$. These depositions may be associated with reduced density of pyramidal cells in the CA1 and CA3 regions of the hippocampus. Moreover, op/op mice exhibit subtle neurodevelopmental defects [12] and increased neuronal vulnerability $[13,14]$, suggesting that CSF1 may also have trophic effects on neurons [15].

M. Axel Wollmer, MD

Division of Psychiatry Research, University of Zurich

August Forel Strasse 1

CH-8008 Zurich (Switzerland)

Tel. +41 44384 2658, Fax +41 44384 2686, E-Mail awollmer@bli.unizh.ch 
Table 1. Characteristics of the investigated samples

\begin{tabular}{lllll}
\hline & Group size & $\begin{array}{l}\text { Age } \\
\text { years }\end{array}$ & $\begin{array}{l}\text { Females } \\
\%\end{array}$ & $\begin{array}{l}\text { APOE } \varepsilon 4 \\
\text { positive, \% }\end{array}$ \\
\hline Sample 1 $(\mathrm{n}=185)$ & $129 / 56$ & $66.6 \pm 9.3 / 70.7 \pm 9.1$ & $49.6 / 53.6$ & $31.0 / 57.1$ \\
Sample 2 $(\mathrm{n}=327)$ & $183 / 144$ & $67.0 \pm 9.1 / 70.2 \pm 8.0$ & $49.2 / 51.4$ & $32.2 / 57.9$ \\
\hline
\end{tabular}

Sample 1 was used for all 3 investigated SNPs. Sample 2 includes sample 1 and was used only for rs1058885. Results are those of healthy control subjects/AD patients.
We assumed that genetic variability of CSF1 may modify amyloid deposition and neurodegeneration in the human brain and thereby the risk for Alzheimer's disease. To test this hypothesis we conducted a genetic case-control association study in a series of $\mathrm{n}=327$ individuals (183 healthy control subjects and 144 cases of sporadic $\mathrm{AD}$, sample 2, table 1) from Switzerland. Diagnoses were made according to the National Institute of Neurological and Communicative Disorders and Stroke/Alzheimer's Disease and Related Disorders Associations (NINCDSADRDA) criteria for probable AD. Dementia and memory deficits in control subjects were excluded by neuropsychological testing, consisting of the Consortium to Establish a Registry for Alzheimer's Disease (CERAD) neuropsychological test battery and the Mini-Mental State Examination (MMSE). The sample is characterized in table 1. The local ethics committee approved the study, and informed consent was obtained from all participants prior to the investigation.

The human CSF1 gene maps to chromosome 1p21p13, $\sim 4.3 \mathrm{cM}$ off the peak marker D1S1678 of a region previously linked to $\mathrm{AD}$ [16]. It comprises $18,898 \mathrm{bp}$ (base pairs 110165499-1101843397 of the chromosomal sequence) with 10 exons and encodes a 554-amino-acid protein. To span the whole locus we used 1 marker upstream (rs3093054) and 1 marker downstream (rs756325) of the gene. We genotyped rs1058885 (T/C, Leu/Pro) to tag the highly variable exon 6 , which harbours 6 of 8 described non-synonymous CSF1 single nucleotide polymorphisms (SNPs) within a sequence of $\sim 470$ bp. Information on SNPs was derived from the NCBI SNP database (http://www.ncbi.nlm.nih.gov/SNP). Genotypes were determined from genomic DNA by Pyrosequencing ${ }^{\mathrm{TM}}$. The following oligonucleotides were used for PCR and sequencing: rs1058885, forward AGGCTCTCCCAGGATCTCAT, reverse biotin-TTCACTTGCTGGTCCTCCTT, sequencing CCCAGGATCTCATCAC; rs3093054, forward biotin-GGAGGGTGGAGAGAAGAACA, reverse AGTGGGACTTGCAGCGTCT,
Table 2. Pairwise linkage disequilibrium of the 3 investigated CSF1 SNPs

\begin{tabular}{|c|c|c|c|}
\hline & rs3093054 & rs1058885 & rs756325 \\
\hline $\begin{array}{l}\text { rs3093054 } \\
\text { [pos. -2,494 bp } \\
\text { C/G, MAF 0.35 (G) } \\
\text { HWE p = 0.1] }\end{array}$ & & $\begin{array}{l}\mathrm{D}^{\prime}=0.078 \\
\mathrm{r}^{2}=0.006 \\
\chi^{2}=1.935 \\
\mathrm{p}=0.164\end{array}$ & $\begin{array}{l}\mathrm{D}^{\prime}=0.221 \\
\mathrm{r}^{2}=0.015 \\
\chi^{2}=5.493 \\
\mathrm{p}=0.019\end{array}$ \\
\hline $\begin{array}{l}\text { rs1058885 } \\
\text { [pos. 13,009 bp (AA 408) } \\
\text { T/C (L/P), MAF 0.4 (C) } \\
\text { HWE p }=0.18 \text { ] }\end{array}$ & & & $\begin{array}{l}\mathrm{D}^{\prime}=0.839 \\
\mathrm{r}^{2}=0.204 \\
\chi^{2}=72.777 \\
\mathrm{p}=0.000\end{array}$ \\
\hline
\end{tabular}

\section{rs756325}

[pos. $+5,709 \mathrm{bp}$

A/G, MAF 0.14 (G)

HWE $\mathrm{p}=0.77$

rs105885 and rs756325 formed haplotypes for which the gametic phase could be predicted with a probability of $>95 \%$ for all individuals with genotypes for both contributing SNPs. Three haplotypes were common (T/A, 84.3\%; C/A, 39.9\%; C/G, 25.3\%), and 1 haplotype was rare (T/G, 2.2\%). None of the 4 haplotypes was associated with $\mathrm{AD}(\mathrm{T} / \mathrm{A}, \mathrm{p}=1.0 ; \mathrm{C} / \mathrm{A}, \mathrm{p}=0.62 ; \mathrm{C} / \mathrm{G}, \mathrm{p}=$ 1.0; $\mathrm{T} / \mathrm{G}, \mathrm{p}=0.08$; Fischer's exact test). rs3093054 was not in linkage disequilibrium with rs1058885 and was weakly linked to rs756325. The left column characterizes the investigated SNPs. Pos. = position relative to the gene; $-=$ a position $5^{\prime}$ upstream; $+=$ a position $3^{\prime}$ downstream of the gene; $\mathrm{AA}=$ affected amino acid; $\mathrm{MAF}=$ minor allele frequency. The $\mathrm{p}$ value is the significance of the deviation from Hardy-Weinberg equilibrium (HWE).

sequencing GGATCTGCTTGATGTGG; rs756325, forward biotin-TTCCTCСССТCAAAAGGATT, reverse GGGTCACAAAGGACTCAAGC, sequencing CCTGGTGGATTTAGGG. The investigated SNPs and their haplotypes are characterized in table 2 . 
Table 3. Genotypic distribution of the three CSF1 SNPs between $\mathrm{AD}$ cases and healthy control subjects

\begin{tabular}{llll}
\hline rs3093054 & AD $(\mathrm{n}=54)$ & HCS $(\mathrm{n}=123)$ & Total $(\mathrm{n}=177)$ \\
\hline $\mathrm{C} / \mathrm{C}$ & $22(40.7 \%)$ & $49(39.8 \%)$ & $71(40.1 \%)$ \\
$\mathrm{C} / \mathrm{G}$ & $26(48.1 \%)$ & $63(51.2 \%)$ & $89(50.3 \%)$ \\
$\mathrm{G} / \mathrm{G}$ & $6(11.1 \%)$ & $11(8.9 \%)$ & $17(9.6 \%)$ \\
& $\mathrm{OR}=1.03,95 \% \mathrm{CI}=0.64-1.65$, Pearson $\chi^{2}=0.01$, \\
& 1 d.f., $\mathrm{p}=0.91(\mathrm{p}=0.95)$
\end{tabular}

\begin{tabular}{lllc}
\hline rs1058885 & AD $(\mathrm{n}=144)$ & HCS $(\mathrm{n}=183)$ & Total $(\mathrm{n}=327)$ \\
\hline $\mathrm{T} / \mathrm{T}$ & $53(36.8 \%)$ & $70(38.3 \%)$ & $123(37.6 \%)$ \\
$\mathrm{T} / \mathrm{C}$ & $65(45.1 \%)$ & $81(44.3 \%)$ & $146(44.6 \%)$ \\
$\mathrm{C} / \mathrm{C}$ & $26(18.1 \%)$ & $32(17.5 \%)$ & $58(17.7 \%)$ \\
& OR $=1.04,95 \% \mathrm{CI}=0.76-1.43$, Pearson $\chi^{2}=0.07$, \\
& 1 d.f., $\mathrm{p}=0.79(\mathrm{p}=0.80)$
\end{tabular}

\begin{tabular}{llcc}
\hline rs756325 & AD $(\mathrm{n}=54)$ & HCS $(\mathrm{n}=124)$ & Total $(\mathrm{n}=178)$ \\
\hline $\mathrm{A} / \mathrm{A}$ & $37(68.5 \%)$ & $92(74.2 \%)$ & $129(72.5 \%)$ \\
$\mathrm{A} / \mathrm{G}$ & $15(27.8 \%)$ & $31(25.0 \%)$ & $46(25.8 \%)$ \\
$\mathrm{G} / \mathrm{G}$ & $2(3.7 \%)$ & $1(0.8 \%)$ & $3(1.7 \%)$ \\
& $\mathrm{OR}=1.39,95 \% \mathrm{CI}=0.75-2.58$, Pearson $\chi^{2}=1.11$, \\
& 1 d.f., $\mathrm{p}=0.29(\mathrm{p}=0.31)$ & \\
\hline
\end{tabular}

There was no significant association of the investigated SNPs with the diagnosis of AD. Statistics refer to the comparison of the 2 alleles of the respective SNPs between the AD and the HCS group. $\mathrm{p}$ values in brackets were obtained by forward unconditional logistic regression, correcting for age, sex, presence or absence of at least 1 APOE $\varepsilon 4$ allele and the respective other CSF1 SNPs. HCS $=$ Healthy control subjects.

None of the 3 markers or their haplotypes were associated with $\mathrm{AD}$ risk in a sub-sample of $\mathrm{n}=185$ individuals (sample 1, table 1), using $\chi^{2}$ tests and forward unconditional logistic regression controlling for apolipoprotein $\mathrm{E}$ $(A P O E)$, age and sex (tables 2, 3). Because linkage to AD on chromosome 1 was predominantly observed in $A P O E$ $\varepsilon 4$ allele carriers [16], we also stratified for $A P O E \varepsilon 4$. In the $\varepsilon 4$-positive subset $(\mathrm{n}=71)$ we found a borderline significance of rs1058885 (linear-by-linear $\chi^{2}$ test, $\mathrm{p}=0.03$ ). To corroborate this observation we increased the sample size to $\mathrm{n}=327$ (sample 2 , table 1 ). In the enlarged sample the effect was disrupted (linear-by-linear $\chi^{2}$ test, $\mathrm{p}=$ 0.06 ), and rs 1058885 also remained negative in the combined sample of APOE- $\varepsilon 4$-allele-positive $(\mathrm{n}=140)$ and -negative participants (table 3 ).

Based on functional and positional criteria, CSF1 was selected as a candidate risk gene for AD. In summary our data do not support the hypothesis that genetic variabil- ity of $C S F 1$ may contribute to the risk for sporadic AD in the investigated population. We emphasize that the present study does not exclude CSF1 as an AD susceptibility gene because of 2 main reasons. (I) Low statistical power: the relative risk associated with the minor alleles of the 3 SNPs that would have been detectable with $80 \%$ power at a significance level of $\mathrm{p}=0.05(\mathrm{n}=185)$ was between 0.13 and 0.37 or 2.47 and 3.10 , respectively. Conversely, the power to reach a significance level of $\mathrm{p}=0.05$ for the observed relative risks was between 4 and 11\%. (II) Low resolution: with 3 SNPs across the CSF1 locus the resolution was about $9 \mathrm{~kb}$. The linkage disequilibrium and allele frequencies of the investigated markers did not capture the whole genetic variability of CSF1.

CSF1 may play an important role in the regulation of the microglial response to amyloid pathology in AD. Over-expression of the CSF1 receptor facilitates the phagocytosis of antibody-opsonized $\mathrm{A} \beta$ by microglial cells [17], which is a potentially important mechanism in immune therapy of AD. Future studies could assess if CSF1 SNPs are associated with responsiveness to active or passive $A \beta$ vaccination, if CSF1 may serve as a biomarker to monitor the microglial response to this treatment, or if CSF1 has a therapeutic potential alone or as an adjuvant in the immune therapy of AD.

\section{Acknowledgement}

We thank Ms. Esmeralda Gruber and Ms. Christin Wilde for their patient care and sampling and Ms. Kim-Dung Huynh for her excellent technical assistance. This work was supported by the National Center for Competence in Research (NCCR), Neuronal Plasticity and Repair, and by the EU APOPIS programme (contract LSHM-CT-2003-503330). 


\section{References}

1 Rogers J, Strohmeyer R, Kovelowski CJ, Li R: Microglia and inflammatory mechanisms in the clearance of amyloid $\beta$ peptide. Glia 2002;40:260-269.

- 2 Simard AR, Soulet D, Gowing G, Julien JP, Rivest S: Bone marrow-derived microglia play a critical role in restricting senile plaque formation in Alzheimer's disease. Neuron 2006;49:489-502.

- 3 Du Yan S, Zhu H, Fu J, Yan SF, Roher A, Tourtellotte WW, Rajavashisth T, Chen X, Godman GC, Stern D, Schmidt AM: Amyloid- $\beta$ peptide-receptor for advanced glycation endproduct interaction elicits neuronal expression of macrophage-colony stimulating factor: a proinflammatory pathway in Alzheimer disease. Proc Natl Acad Sci USA 1997;94:5296-5301.

4 Hao AJ, Dheen ST, Ling EA: Expression of macrophage colony-stimulating factor and its receptor in microglia activation is linked to teratogen-induced neuronal damage. Neuroscience 2002;112:889-900.

5 Mitrasinovic OM, Vincent VA, Simsek D, Murphy GM Jr: Macrophage colony stimulating factor promotes phagocytosis by $\mathrm{mu}$ rine microglia. Neurosci Lett 2003;344:185188.

6 Murphy GM Jr, Zhao F, Yang L, Cordell B: Expression of macrophage colony-stimulating factor receptor is increased in the $\mathrm{A} \beta \mathrm{PP}(\mathrm{V} 717 \mathrm{~F})$ transgenic mouse model of Alzheimer's disease. Am J Pathol 2000;157: 895-904.
7 Wegiel J, Wisniewski HM, Dziewiatkowski J, Tarnawski M, Kozielski R, Trenkner E, Wiktor-Jedrzejczak W: Reduced number and altered morphology of microglial cells in colony stimulating factor-1-deficient osteopetrotic op/op mice. Brain Res 1998;804: 135-139.

8 Raivich G, Moreno-Flores MT, Moller JC, Kreutzberg GW: Inhibition of posttraumatic microglial proliferation in a genetic model of macrophage colony-stimulating factor deficiency in the mouse. Eur J Neurosci 1994;6: 1615-1618.

9 Kalla R, Liu Z, Xu S, Koppius A, Imai Y, Kloss CU, Kohsaka S, Gschwendtner A, Moller JC, Werner A, Raivich G: Microglia and the early phase of immune surveillance in the axotomized facial motor nucleus: impaired microglial activation and lymphocyte recruitment but no effect on neuronal survival or axonal regeneration in macrophage-colony stimulating factor-deficient mice. J Comp Neurol 2001;436:182-201.

10 Kaku M, Tsutsui K, Motokawa M, Kawata T, Fujita T, Kohno S, Tohma Y, Ohtani J, Tenjoh $\mathrm{K}$, Tanne K: Amyloid $\beta$ protein deposition and neuron loss in osteopetrotic (op/op) mice. Brain Res Brain Res Protoc 2003;12: 104-108.

11 Kawata T, Tsutsui K, Kohno S, Kaku M, Fujita T, Tenjou K, Ohtani J, Motokawa M, Shigekawa M, Tohma Y, Tanne K: Amyloid $\beta$ protein deposition in osteopetrotic (op/op) mice is reduced by injections of macrophage colony stimulating factor. J Int Med Res 2005;33:654-660.
12 Michaelson MD, Bieri PL, Mehler MF, Xu H, Arezzo JC, Pollard JW, Kessler JA: CSF-1 deficiency in mice results in abnormal brain development. Development 1996;122:26612672.

13 Fedoroff S, Berezovskaya O, Maysinger D: Role of colony stimulating factor-1 in brain damage caused by ischemia. Neurosci Biobehav Rev 1997;21:187-191.

14 Bruccoleri A, Harry GJ: Chemical-induced hippocampal neurodegeneration and elevations in TNF $\alpha$, TNF $\beta$, IL- $1 \alpha$, IP-10, and MCP-1 mRNA in osteopetrotic (op/op) mice. J Neurosci Res 2000;62:146-155.

15 Mitrasinovic OM, Grattan A, Robinson CC, Lapustea NB, Poon C, Ryan H, Phong C, Murphy GM Jr: Microglia overexpressing the macrophage colony-stimulating factor receptor are neuroprotective in a microglialhippocampal organotypic coculture system. J Neurosci 2005;25:4442-4451.

16 Myers A, Wavrant De-Vrieze F, Holmans P, Hamshere M, Crook R, Compton D, Marshall H, Meyer D, Shears S, Booth J, Ramic D, Knowles H, Morris JC, Williams N, Norton $\mathrm{N}$, Abraham R, Kehoe P, Williams H, Rudrasingham V, Rice F, Giles P, Tunstall N, Jones L, Lovestone S, Williams J, Owen MJ, Hardy J, Goate A: Full genome screen for Alzheimer disease: stage II analysis. Am J Med Genet 2002;114:235-244.

17 Mitrasinovic OM, Murphy GM Jr: Microglial overexpression of the M-CSF receptor augments phagocytosis of opsonized $\mathrm{A} \beta$. Neurobiol Aging 2003;24:807-815. 